\title{
THE APPLICATION OF LOUD READING IN TEACHING PRONUNCIATION AT MTSN BANDA ACEH II
}

\author{
Mauloeddin Afna \\ IAIN Langsa \\ mauloeddin@gmail.com
}

\begin{abstract}
This study was conducted to investigate class activity in drilling pronunciation for English subject at junior high school level. It was conducted at MTsN Banda Aceh II, Aceh. To collect the data, the researcher used test, observation and interview. The students were taught by loud to improve students' pronunciation in English. Several paragraphs were taken in charge of supporting loud reading drills. The drills took 45 minutes in one section. Test was used to identify the success of loud reading in teaching pronunciation. Observation, on the other hand, was designed to observe the school environment, teaching method, and students' assessment. In addition, interview was carried out informally to the headmaster and teachers of MTsN Banda Aceh II. This study reveals that the mean is 80.2 . This shows a positive use of the loud reading applied at the school. The study also exposes that this method is effective to help their reading ability and to maintain their pronunciation. Thus, the researcher concludes that loud reading has been effectively boosted the students' pronunciation.
\end{abstract}

Keywords

Loud reading, pronunciation, reading drills and reading ability

\section{INTRODUCTION}

Pronunciation is one of important elements in English language. In speaking, pronunciation determines the intended meaning. It is important for language users to assign meaning to what is heard. As a current situation that occurs today, some students understand the meaning, but hardly ever can express the words on spoken language. The importance of pronunciation here is designed to help the students to pronounce the words correctly. Pronunciation helps students to be familiar and recognize the spoken English language in spite of their own mother tongue or their first language. 
Concerning to the above paragraph, the study focused on the application of loud reading applied in teaching pronunciation. This is one of the strategies for foreign language learning. The teaching covered the most frequent vocabularies used in daily talk. Moreover, the school teachers, as the object of study, taught the daily used vocabularies because they are easy to memorize for junior high school students.

The core element in learning pronunciation is vocabulary articulation. The element emphasizes the phonetics; the way of English sounds words. This element is supported by several ideas. First, vocabularies lead to four major English skills, such as listening, reading, speaking, and writing. Pronunciation plays an important role. It is the first layer to cover before moving forward to another layer as viewed by Howatt in Richards, et. all (2003: 153-154):

By the end of sixties it was clear that the situational approach....had run its course. There was no future to pursue the chimera of predicting language on basis of situational events. What was required was a closer study of language itself and a return to traditional concept that utterances carried meanings and intentions of speaker and researcher who created them.

The above quotation shows that pronunciation determines the intention of speaker's utterance. To help the students overcome their difficulties in pronouncing English words, a loud reading was introduced to help them to pronounce the words correctly.

In the application of loud reading the strategy in teaching pronunciation, some essays were adopted as the teaching materials. The materials were taken from newspaper, internet, tabloid, book, story and so on, and they are suitable for junior high school level. The teacher handed out one of the materials and helps students who find difficult words to pronounce by using dictionary. Then, the teacher read the materials three 
times, pronounced the words, repeated them for several times and wrote the meaning of difficult words.

According to the researcher's preliminary study, this school had used this loud reading in teaching pronounciation correctly. Furthermore, when they read a passage, their articulations were well articulated based on the standard English. It is expected that the study would help the school teachers to identify the problems and to find out feed-back form the students. It is also expected to help teachers in learning and teaching English as a foreign language that is commonly used by people today. The main aim is to investigate the application of loud reading in teaching.

\section{LITERATURE REVIEW}

Pronunciation is an ability consists of two nouns, pronunciation and ability. The word Pronunciation, according to A.S Hornby (1995), is "making the sound of the word or letter in particular way and it is a manner word utterance. Pronunciation determines meaning and sense of words. So, misspronunciation generates ambiguity and bias. Pronunciation also concerns with an ability to articulate words. In addition, "ability" is the mental or physical capacity or skill required to do actions. Ability in this study is students' attainment from learning foreign language articulations. Moreover, it is equipped along the process of learning. Thus, "Pronunciation Ability" is the mental of language capacity of particular utterances. To specify this study, the researcher focuses on observing the development of English Pronunciation ability through loud reading taught at the second year students' ofMTsN Banda Aceh II by using texts and cassettes. American English pronunciation is a part of world accent beside English British and Australian. The accentis also known as U.S English. The accents are traced 
from the early seventeenth century when the English colony began to live in new land that is called America. The colony urged to find an Identity about one new unity that is out of British authority. The American colony consisted working class families, extradited politicians, noblemen or even criminals. This mixed society began to live and to find out their culture. These issues also rooted in American linguistics habit with opposite's direction form, American here, seek liberty. The American tendency moved to a liberal inclusiveness, and allowed a less problem relationship between speaker and addressee and a larger social unit. According to the poet and polemicist Thomas Davis (2002) which marshaling the argument of a letter day Herder in defense of the untranslatable, a quotation from Rod Mengham in;

The language which grows up with a people is conformed to their organs, descriptive of their climate, constitution and manners, mingled inseparably with their history and their soil, fitted beyond any other language to expresses their prevalent thought in most natural way. To impose another language on such a people is to send their history adrift among the accidents of translation.

Thus, the root of language started from the culture. And it was influenced by the development of human actions in linguistics. The transformation of a language within pronunciation spreads orally in daily action. The society accepted this accent and settled it to be an accepted accent, and it was changed arise of translation. Moreover, the accent turned to be a standard of language. The transformation process also called as language assimilation. Yet, the process cannot be applied unless there was a linguist who was incharged in this issue. The response of linguist transformation in English structure by Noam Chomsky (2008), "the linguist, Noam Chomsky, has demonstrated that the current standard structural theories of language were incapable of accounting for fundamental characteristic of language-the 
creativity and uniqueness of individual sciences" Noam Chomsky views that it is important for the language users to maintain the order of words, and utterances seriously even the language refers to the users themselves. The utterances as Noam Chomsky said before are pronunciation. Another response of language process is the British linguist, D. A Wilkins, the linguist concerned about the language should utter clearly in order to clear out the meaning.

Received Pronunciation (RP) "is a form of pronunciation of the English language which has been long perceived as uniquely prestigious among British accents and is the usual accent taught to non-native speakers learning British English". Received Pronunciation also sometimes refers to the Queen's English or the King's English, because it is spoken by the monarch, or BBC English, because it was traditionally used by the BBC. Yet, nowadays, these are all slightly misleading. The queen, Elizabeth II, speaks an almost unique form of English, and the BBC is no longer restricted to one type of accent, nor is Oxbridge. RP is an accent (a form of pronunciation), not anaccent (a form of vocabulary and grammar). It shows a great deal of the social and educational background of person who uses British English. A person using an RP accent will typically (except for comic effect) speak Standard English although the reverse is not necessarily true. In recent decades,

"Many people have asserted the value of other regional and class accents, and many members (particularly young ones) of the groups that traditionally used Received Pronunciation have moved away from it to varying degrees. A wide range of regional accents are now heard on the BBC. There are signs that RP is losing its status as "normal English" (but not its identity as "posh English") to the "Estuary English" accent".

General American sometimes, called Standard Midwestern, Standard 
Spoken American English or American Broadcast English, is the accent of American English perceived by Americans to be most "neutral" and free of regional characteristics. The General American accent is not thought of as a linguistic standard in the sense that Received Pronunciation (RP) has historically been the standard, prestigevariant in England, but its speakers are perceived as "accent less" by most Americans. Within American English, General American and accents approximating it are contrasted with Southern American English, several Northeastern accents, and other distinct regional accents and social group accents like African American Vernacular English. Mengham (2012: 47) "General American—like the British Received Pronunciation as well as most standard language varieties of many other societies-was never the accent of the entire nation". Rather, it is most closely related to a generalized Midwestern accent and is spoken particularly by many newscasters, in part because the national broadcasters preferred to hire people who exhibited similar speech. Famous news anchor, Walter Cronkite, is a good example of a broadcaster using this accent. Since Cronkite was born in Missouri, and spent his first dozen years there, one assumed that, somehow General American was the regional accent of the state, although Cronkite's teen years were spent in Texas, which is not known for having "accent less" speakers. General American is also the accent generally taught to people learning English as a second language in the United States, as well as outside the country to anyone who wishes to learn American English.

Loud Reading, the compound, composes in two words; they are "loud" and "reading". Loud is as adjective, therefore, it is "produce much noise and easily heard", furthermore, loud used as higher volume of voiced words in leading to the teacher can crop students' pronunciation clearly. In addition, Reading is "the process of retrieving and comprehending of some stored information forms or even 
ideas".Therefore, "Loud Reading", in this study, is defined as the process to retrieve students' pronunciation in loud voice.Thus, Loud Reading is a learning strategy. It is designed to make students accustomed to English language pronunciation. Therefore, students can improve their pronunciation through loud reading. In addition, Derek Kelly (2009) views that "Loud Reading is the simple method to learn English practically for students who are not native speaker" Therefore, loud reading is a learning strategy to improve students' pronunciation. Loud reading trained students to read out loud with speed, accuracy, and proper expression. In addition, it encourages students to read with loud voice systematically and it provides feedback to the teacher about the mistakes of students' pronunciation. Loud reading also may be applied as language acquisition method, such as listening with cassettes, orally conversation, reading short texts.

\section{RESEARCH METHOD}

This study is a descriptive study focusing on the use of loud reading in teaching pronunciation. The research instruments were observation, test, and interview.

The researcher tested directly the student's comprehension, demand of language assessment, motivaton, related the students performance in pronouncing the words. Moreover, researcher also observed the nature of school, curriculum that is implemented and the English teachers' ability not only at teaching and learning, but also their English mastery or the feedback after learning.

The population of the study is all the second year students of MTsN Banda Aceh II. The sample was selected randomly. Three students from 5 classes were randomly selected to participate in this study. Thus the total 
sample of this study was 15 from different background of family, range of learning assessment, and English learning initiative. To gather more information in the use of loud reading, English subject teacher from the second year students were interviewed.

The Test, pronunciation test, is given to crop the evaluation measurement of the students' progression. Yet, in this study, the test goal is to measure the students' pronunciation ability. The test was carried out through reading dialogues. The material of the test was taken from the materials that have been taught. Interview was designed to identify the students' obstacles and as a media to gather the information from the teachers related to the application loud reading.

To analyze the test, the mean of the students' level of performance was statistically calculated and consulted to the criteria determined by the school, while the observation and were analyzed qualitatively.

\section{FINDINGS AND DISCUSSION}

The application of the loud reading in teaching pronunciation was done through drilling activities. The teacher asked some students to read the paragraph loudly for three times, while the rest of the students listened. The students, then, were asked to write the meaning of difficult words on their paper. In this meeting, to support the students and teaching process, the teacher collected the words that are difficult to pronounce. The teacher gave explanation about the loud reading function. The teacher also asked students to pronounce the words loudly. In addition, the students used to play a game such as word game which became helpful to enhance the students' ability and motivation in pronouncing the words in a more relaxed situation. 
The study reveals that the students have a good level of performance in pronunciation as indicated by the mean score of the student. The mean score of the students is 80.2 which shows a very positive use of the application of loud reading in teaching pronunciation. In addition, the result of questionnaire also indicates a good response from students in learning pronunciation through loud reading.

According to the interview result, the researcher found that students did not face much difficulty. The interview to some students shows that the frequency in playing word game helps the students pronounce the words correctly. The study discloses that students who occasionally play English word game perform better and easier in pronouncing the words, while students who seldom play the game find much difficulty in pronouncing English words. Furthermore, loud reading assimilates English to their language.

\section{CONCLUSION}

The use of loud reading teaching strategy in teaching pronunciation in EFL classroom has been an effective mean in teaching pronunciation. This has been proven by the mean score of the students while doing the given test where the mean score obtained by the students is 80.2. Loud reading, on the other hand, familiarizes the students with English words pronunciation. Loud reading is a simple method; basically, loud reading focuses on reading material loudly and gradually.

The application of loud reading is one of learning strategies that can be applied efficiently by any person. To improve the success of English teaching and learning process, the researcher suggests the English teachers generate students' motivation to read English texts. English teachers also 
should maintain the current pronunciation of accepted standard, before teaching reading or spelling. Moreover, the teacher should maintain the environment of teaching, learning and material of text. The students should know English not only as a subject, but also as a global language. It is important to learn English within various ways.

\section{REFERENCE}

Atunez, Beth. (2002). Implementing Reading First with English Language Learners. National Clearinghouse for English Language Acquisition \& Language Instruction Educational Programs; Directions in Language and Educations,(15).

Clifford, H. Prator, Jr. (1971). Manual of American English Pronunciation: Third Edition. University of California: Los Angles.Press.

Given, Lisa M. (2008). The Sage encyclopedia of qualitaive research method.Research Method Encyclopedia. United Stated of America : SAGE Publication, Inc.

Hornby, A. S. (1995). Oxford Advanced Learner's Dictionary of Current English. Oxford University press.

Jones, Daniel. (1956). The Pronunciation of English: Definitive Edition (4.ed.). Melbourne: Cambridge University press.

Kelly, Derek. (2007). The Technique in teaching and measuring classroomloud reading. International Journal of Teaching English as Second Language. http://itesli.org/Techniques/Kelly-ReadingAloud.html

Lettinga, F. (2010). English Phonetics: for the B-1 courses in Indonesia. Semarang : teacher of English M.O leader of The B-1English Courses.

Mary Waters and Alan Water. (1995). Study Task in English: Student's Book. Melbourne: Cambridge University press.

Nunan, David. (1999). Second Language Teaching and Learning. Boston; Massachusetts: Heinle\&Hienline Publishers. 
Raymond C. Clark. (2002). Index Card Games for ESL (1.ed.)Vermont: Prolingua Associates Barattlebaro.

Richards, Jack C. and Rodgers, Theodore S. (2003). Approach and Methods in language Leaning (4.ed.). Cambridge University press. 